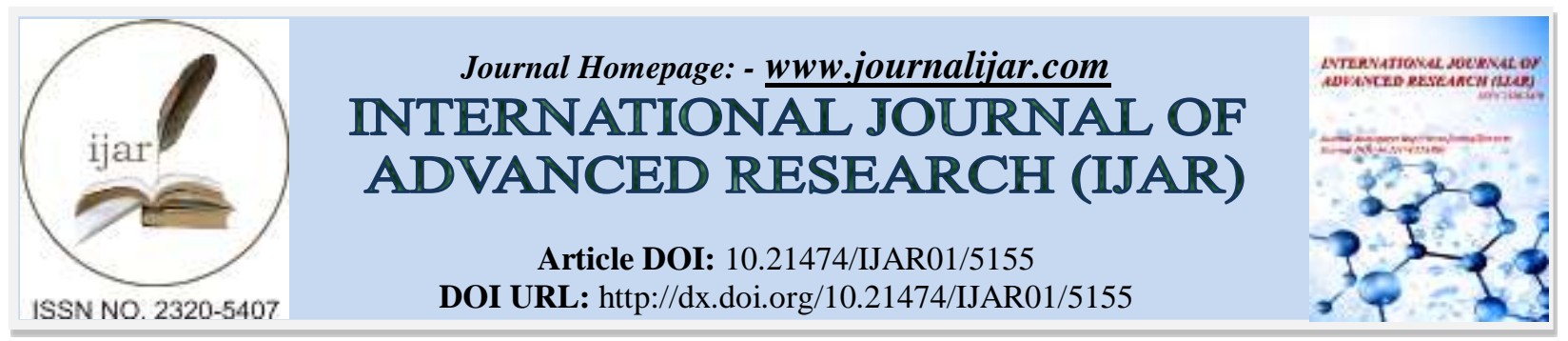

RESEARCH ARTICLE

\title{
QUALITY MANAGEMENT PRACTICES: BASIS FOR INNOVATIVE PERFORMANCE OF TEACHER PREPARATION PROGRAM OF SELECTED STATE UNIVERSITIES AND COLLEGES IN THE CALABARZON REGION.
}

\author{
Maria eva e. Diongco, ed. D. \\ College of Teacher Education Research Coordinator, Laguna State Polytechnic University Sta. Cruz Campus \\ Laguna, Philippines.
}

\section{Manuscript Info}

Manuscript History

Received: 13 June 2017

Final Accepted: 15 July 2017

Published: August 2017

Key words:-

Quality management practices, innovative performance, graduates' work valuesknowledge and skills.

\section{Abstract}

This descriptive correlation study was conducted to determine the performance of teacher education program to establish the effect of faculty members endeavours and the quality management practices on the graduates' performance.

The respondents were program managers i.e., vice-presidents for academic affairs, deans and program heads with selected faculty and student teaching supervisors from the teacher preparation programs of five selected SUCs in the CALABARZON region during the academic year $2014-2015$.

A researcher-constructed questionnaire was used to gather the needed data. Descriptive as well as inferential statistics and multiple regressions were used to establish the qualitative dimensions of the problems posed.

The faculty in general perceived that the graduates of teacher preparation programs have effective interpersonal competencies as evidenced by the overall mean of 4.51 , interpreted as highly evident and excellent knowledge and skills as disclosed by the grand mean of 96.658.

Participation in research activities was found to have a significant effect on quality management practices of teacher preparation program among the respondent universities and that the excellent resource management significantly affected the graduates' positive work values.

Copy Right, IJAR, 2017,. All rights reserved.

\section{Introduction:-}

Education is an ongoing process of transformation that includes empowerment and enhancement of the students (Ekankumo \& Kemebaradikumo, 2014). In a school system, the management sub-system, technical sub-system and social sub-system are based on principles of quality management practices implemented to satisfy the needs of the students and other stakeholders. It is vital to include within its ambit the quality of inputs in the form of students, faculty, support staff, infrastructure, the quality of teaching-learning processes and the quality of outputs in the form of enlightened students.

The provisions of the policy standard to enhance quality assurance in Philippine higher education as embodied in Commission on Higher Education Memorandum Order (CMO) 46 series of 2012 Section 2 stipulates that Philippine 
higher education shall produce thoughtful graduates imbued with values reflective of a humanist orientation. As the mission of the Philippine higher education is to produce graduates with high levels of academic thinking, behavioral and technical skills or competence that are aligned with national academic and industry standards and needs or international standards. The state universities and colleges (SUCs) in the CALABARZON region strive to respond to this call.

But the extent to which the teacher preparation programs in SUCs respond to this call for quality in education is not fully established. There is a need to determine how the program managers and the faculty provide learning opportunities to the graduates that developed their competencies in terms of showing commitment to the teaching profession, taking initiative in performing tasks, being resourceful in the use of teaching strategies, and exuding effective human relations to gain their superior's and peer's cooperation and respect.

\section{Statement of the Problem:-}

The primary aim of the study was to determine the extent of graduates' competencies provided by the teacher preparation programs in SUCs as guided by quality management practices.

Specifically, it intended to answer the following problems:

1. What is the profile of the faculty respondents in terms of:
1.1 Highest educational attainment,
1.2 Area of specialization, and
1.3 Research function as to:
1.3.1 Research conducted,
1.3.2 Research presented,
1.3.3 Research patented/ copyrighted, and
1.3.4 Awards received in research?

2. What is the perceived/observed quality management practices observed in the teacher preparation programs along:

2.1 Management practices:

2.1.1 Resource management and

2.1.2 Goal setting

2.2 Good governance:

2.2.1 Transparency,

2.2.2 Accountability,

2.2.3 Integrity, and

2.2.4 Sustainability

2.3 Curriculum factors in:

2.3.1 Curriculum enhancement,

2.3.2 Training delivery,

2.3.3 Learning materials design,

2.3.4 Highest level of accreditation, and

2.3.5 Supervised industrial training?

3. How do the respondents perceived the performance of the teacher preparation programs in terms of the graduates':

3.1 Work values as to:

3.1.1 Commitment,

3.1.2 Initiative, and

3.1.3 Human relations

3.2 Knowledge and skills as reflected by:

3.2.1 Final grade in practice teaching?

4. Is there a significant effect of the faculty profile on the teacher preparation program?

5. Do the observed quality management practices in the teacher preparation program in SUCs affect the teacher preparation program of SUCs?

Review of Related Literature and Studies:-

Profile of Faculty:-

The highest educational attainment of persons serve as their weapon and motivation in working for the best of the program; the higher their educational qualification the better and more capable they are in playing their roles in 
pursuit for quality and excellence of the program (Ganal, 2014). School heads with higher educational qualification can provide guidance to teachers in handling different situations as well as other processes that could influence the teachers' performance; they effectively incorporate knowledge and skills for the progress of the school.

Faculty and students from SUCs are encouraged to do collaborative national or international research where they collectively investigate scientific problems utilizing the strengths and capabilities of each individual and institution. This is one avenue to achieve quality in education and one of the indicators of the success of a college or university as pointed by Ganal (2014).

Exposures to research activities equip faculty members with innovative thinking that are useful in the improvement of instructional processes. As stressed by Pirkhaefi (2004), educational organizations and especially educational systems have a great role in improving human's life. Innovative and creative individuals in educational system and other educational and scientific centers are vital in educating committed and knowledgeable workforce.

\section{Quality Management Practices:-}

Quality is a major factor affecting an organization's performance. It is an essential part of the strategy of any organization in the competitive arena, whether they compete globally, nationally or locally. For instance, in monitoring and evaluation of teacher preparation program, there is a need to determine if the program is being delivered with good practice and conforms to national standards (Necesito, Santos, \& Fulgar, 2010).

Other universities do not simply focus on human resources development but also in other operation procedures. For instance, the Educational Leadership Policy Standards, that contain the domains for principal professional practice, highlight that school principals should ensure effective management of the organization, operation, and resources for a safe, efficient, and effective learning environment and collaborate with faculty and community members, responding to diverse community interests and needs, and mobilizing community resources (Condon \& Clifford, 2012).

The extent to which program managers or school administrators set clear goals for the institution may result to a more effective school management. Goal setting is a process intended to increase efficiency and effectiveness by specifying the desired outcomes toward which individuals, departments, teams, and organizations should work (Slocum \& Hellriegel, 2007).

Governance comprises a complex web including the legislative framework, the characteristics of the institutions and how they relate to the whole system, how money is allocated to institutions and how they are accountable for the way it is spent, as well as less formal structures and relationships which steer and influence behaviour (OECD, 2008).

Accountability cannot be enforced without transparency and the rule of law; organizations that deliver and sustain superior results by inculcating high expectations across all levels of the organization are instilling ownership and accountability. In this effect, the managers are called multipliers who can hold people accountable for their commitments (Wiseman \& McKeown, 2010). While Cheema (2002) emphasized that accountability, ethics and integrity are points in a continuum.

\section{Curriculum Factors:-}

The curriculum in teacher preparation programs in SUCs incorporate value orientations underlying curricular decision-making, selection and statement of curriculum goals, identification and organization of programme content, and the process of curriculum change. This is because education must deal with the needs of the current culture and even helps shape the future (Andres \& Francisco, 2010).

A means to assess if educational institutions exceed the standards and requirements is through accreditation. Meeting the prescribed requirements for national recognition or going beyond the minimum requirements of competencies is a significant index that the goals and programs of the educational institutions carry relevance, quality and excellence (Ganal, 2014).

Education in school system is not an end in itself, but a means of achieving greater things in ones' career, there is need for mutual cooperation between the school system and industry in raising the technical literacy of technology, 
engineering and applied sciences students. The study made by Akerejola (2008), showed that majority of the students who go out in industrial training claimed that they did not receive adequate skills, because of their inability to secure placement in well-equipped establishments. Consequently, the law on students' industrial work experience scheme (SIWES), which make it mandatory for industrial establishments to accept students, should be enforced.

\section{Teacher Preparation Program:-}

The performance of teacher preparation programs in SUCs, in this study, pertains to the graduates' work values, knowledge and skills. The work values of the graduates' cover commitment, initiative, and human relations while knowledge and skills were reflected by their final grades in student teaching.

A common feature of all teacher education programs in Organization for Economic Co-operation and Development (OECD) countries is the provision of field experience or teaching practice for student teachers. The duration of teaching practice varies widely from country to country. Some programs provide for brief periods of classroom placement, others have yearlong internships, with students being assigned regular teaching obligations. Many OECD countries are now rethinking the role of teaching practice. Increasingly, students are being given experience in schools earlier in their teacher education program, and practice is being broadened to encompass the responsibilities of teachers beyond the classroom, particularly in such areas as curriculum and school development planning, research, evaluation, and collaboration with parents and external partners (OECD, 2005).

Students of teacher preparation programs will work as either teachers or employees after graduation; their jobs will engage them on a daily basis and would require a certain level of personal engagement and commitment. In schools, commitment is used to describe the desirable attitudes of a teacher. It is part of the teacher's professional identity and used as a measure of school effectiveness (Crosswell, 2006).

\section{Knowledge and Skills:-}

The knowledge, skills and commitment of teachers, as well as the quality of school leadership, are the most important factors in achieving high quality educational outcomes. It is essential to ensure that those recruited to teaching and school leadership posts are of the highest calibre and well-suited to the tasks they have to fulfill; great care and attention should be devoted to defining the required profile of prospective teachers and school leaders, to selecting them and preparing them to fulfill their tasks (European Union, 2013).

Teacher competence is the ability to meet complex demands, by drawing on and mobilising psychosocial resources in context i.e. a complex action system encompassing knowledge also tacit; cognitive and practical skills; attitudes such as motivation, value orientations, and emotions (Rychen \& Salganik, 2003).

\section{Research Methodology:- \\ Research Design:-}

The descriptive method of research was used in the study, particularly the descriptive correlational design. The multiple regression analysis established the predictor from among the tested variables such as profile of faculty, quality management practices of teacher preparation programs to the graduates' work values, knowledge and skills. In this study, the researcher established how the profile of faculty, management practices, good governance, and curriculum factors in the teacher preparation programs in SUCs correlate with the performance of the teacher preparation programs making descriptive-correlational research the most appropriate method to use.

\section{Respondents and Sampling Design:-}

The subjects of the study were 45 program managers composed of the vice-presidents for academic affairs, deans and program heads. The second set of respondents was 150 faculty who have handled the graduates during their $3^{\text {rd }}$ and $4^{\text {th }}$ year and student teaching supervisors from the TPPs of selected SUC's in the CALABARZON.

The multiple regression analysis established the predictor from among the tested variables such as profile of faculty, quality management practices of teacher preparation programs to the graduates' work values, knowledge and skills.

The researcher-made questionnaire-checklist administered to the faculty was composed of six parts. Part I is about the professional attributes of faculty. Part II focused on the research conducted by the faculty. Part III of the questionnaire-checklist for faculty was composed of the management practices. Part IV was devoted to the good governance practices. Part V of the questionnaire-checklist focused on curriculum factors. 
Part VI of the questionnaire-checklist determined the work values of the Teacher Education (TE) graduates as to their commitment, initiative and human relations.

For the knowledge and skills of the TE graduates the final grades in practice teaching for the previous year (20142015).

\section{Results and Discussion:-}

1. The program managers were able to effectively manage the resources in their department to a high extent, and effectively communicate the desired outcomes to faculty and students which encouraged collaboration of every stakeholder.

2. It is highly evident that the program managers carried out the good governance practices in terms of transparency, accountability, integrity and sustainability. They take full responsibility in managing the programs and gain subordinates' trust and respect.

3. The extent of implementation of curriculum enhancement does not differ much in the five SUCs. It was highly evident that the training delivery, the learning materials designs and SIT allow the use of varied strategies and provide varied activities for students' developments responsive to the needs and interests related to students' future jobs locally or internationally.

BSED and BEED programs in SUCs are both accredited at Level III Phase 2 and the BSIE program is at Level III Phase 1.

4. The graduates show high commitment to the school's philosophy, goals, values and reputation. They are generally innovative, manifested creativity in the use of methods of assessment and variety of materials to foster teachinglearning process. The graduates have positive human relations, are generally open-minded; and have leadership skills; they can easily adapt to varied situations.

The mean of the graduates' final grade is 96.66 interpreted as excellent. The standard deviation indicates that the final grade of the graduates in practice teaching did not differ much which implies that the graduates of TPP during practice teaching have showed excellent levels of teaching competencies, classroom management skill, community relations and creativity and innovation.

5. Resource management has a significant effect on the work values of the graduates. This means that effectively managing resources in a university influence the work values of the students.

\section{Summary, Conclusions and Recommendations:-}

The findings of the study yielded the following conclusions:

1. Research profile of the faculty respondents significantly affects the quality management practices and graduates of the teacher preparation program in SUCs.

2. Resource management significantly affects the work values of the graduates of the teacher preparation program.

3. The hypothesis stating that the faculty profile and the quality management practices in the teacher preparationprogram in SUCs do not affect significantly the teacher preparation program of the SUCs is rejected.

On the basis of the findings and conclusions of the study the following recommendations are being offered:

1. It is recommended that the college/university administrators be more conscious and aware on the benefits of having a teaching staff capable of conducting researches. The faculty can reach their full potentials in research by exposing them to seminars and trainings; it is through these means that the faculty can enhance their high research capability which can uplift the university's prestige in terms of research.

2. As the SUC's continuously seek excellence and quality through accreditation, it is highly recommended that they should sustain the effective management and delivery of the teacher education programs based on previous results. The SUC's can use the strengths and recommendations provided by the accrediting agency as baseline information on how to create reforms that would redound to competent faculty and excellent graduates imbued with exemplary skills and work values.

3. It is also recommended that in the involvement of stakeholders in the management of economic resources be increased through participative planning of programs and projects in the university. Through consultation with the stakeholders, effective programs and projects could be initiated where the use of human and non-human resources can be maximized. 


\section{References:-}

1. Akerejola O.(2008) Information and Guidelines for Students Industrial Work Experience Scheme. The Pacific Journal of Science and Technology -238- http://www.akamaiuniversity.us/PJST.htm Volume 10. Number 1. May 2008 (Spring)

2. Cheema, G. S. (2002). Public Service Ethics Global Practices and Tools. Meeting of Sectoral Delegates in Public Ethics. Brasilia, Brazil, 20-21 March 2002. United Nations Department of Economics and Social Affairs. Division for Public Economy and Public Administration. Retrieved from unpan1.un.org/intradoc/groups/public/documents/ un/unpan.010812.pdf

3. Condon, C. \& Clifford, M. (2012). Measuring Principal Performance How Rigorous Are Commonly Used Principal Performance Assessment Instruments. American Institutes for Research.

4. Crosswell, L. (2006). Understanding Commitment in terms of Change. Dissertation, Queensland University of Technology. http://eprints.qut.edu.au/16238/1/Leanne_Crosswell_Thesis.pdf.

5. Ekankumo, B. \& Kemebaradikumo, N. (2014).Quality Education and the Attainment of the Millennium Development Goals (MDGs) in Nigeria: A Case for Quality Teachers. Journal of Education and Practice, Vol.5, No.18, 2014, ISSN 2222-288X.

6. European Union. (2013). Recommendation on Key Competencies for Lifelong Learning. Official Journal of European Union, Brussels, European Union.

7. Necesito, M., Santos, R. B., \& Fulgar, J. I. (2010). A Results-Based Monitoring and Evaluation Framework to Determine Performance and Success of ESD in TVET: The Case of the Philippines. Conference Proceedings, ESD in TVET. Available online from http://www.focusintl.com/RBM077-23. Necesito.pdf.

8. OECD (2005). Curriculum and Leadership Journal: Quality Teaching in Australian Schools. Curriculum Vol. 5 Issue 8.

9. OECD (2008). A Review of Governance Arrangements and Quality Assurance Guidelines.

10. Pirkhaefi, A. (2004). Factors of poor attention to creativity in universities and methods of improving creativity". Creativity and Innovation Quarterly, No.7.

11. Rychen, D.S. \& Salganik, L.H. (2003). Key Competencies for a successful life and a well-functioning society. Göttingen: Hogrefe \& Huber.

12. Slocum, J. W. \& Hellriegel, D. (2007). Fundamentals of Organizational Behavior. Mason, OH: Thomson SouthWestern.

13. Wiseman, E. \& McKeown, G. (2010). Multipliers. How the Best Leaders Make Everyone Smarter. New York: HarperCollins Publishers. 